\title{
Research Group in Orchids, Ecology and Plant Systematics: an inter-institutional initiative for plant conservation and sustainable use in south-west Colombia
}

\author{
Nicola S. Flanagan ${ }^{1 *}$, A. T. Mosquera-Espinosa ${ }^{1}$, R. T. González ${ }^{2}$, \\ F. H. Molineros-Hurtado ${ }^{2,3}$, N. H. Ospina-Calderón ${ }^{4}$, M. Cuartas-Domínguez ${ }^{5}$, \\ P. A. Silverstone-Sopkin ${ }^{6}$, G. Reina ${ }^{7}$, M. C. Diez ${ }^{8}$, R. Ospina-Torres 9 , \\ J. D. ACKerman ${ }^{10}$, P. BAYMAN $^{10} \&$ J. T. OTERO ${ }^{3,11}$
}

\begin{abstract}
${ }^{1}$ Biology Program, Pontificia Universidad Javeriana, Cali, Colombia; ${ }^{2}$ Agronomy Program, Universidad del Pacífico, Buenaventura, Colombia; ${ }^{3}$ Biological Sciences Department, Universidad Nacional de Colombia, Palmira, Colombia; ${ }^{4}$ Ecology Program, Fundación Universitaria de Popayán, Colombia; ${ }^{5}$ Acta Agronomica Journal, Universidad Nacional de Colombia, Palmira, Colombia; ${ }^{6}$ Biology Department, Universidad del Valle, Cali, Colombia; ${ }^{7}$ Biology Department, Universidad de Barcelona, Spain; ${ }^{8}$ Forestry Department, Universidad Nacional de Colombia, Medellín, Colombia; ${ }^{9}$ Biology Department, Universidad Nacional de Colombia, Bogotá, Colombia;

${ }^{10}$ Department of Biology, University of Puerto Rico-Rio Piedras; 11Environmental Studies Institute (IDEA Palmira), Universidad Nacional de Colombia, Palmira, Colombia

Author for *correspondence: nsflanagan@javerianacali.edu.co
\end{abstract}

The Research Group in Orchids, Ecology and Plant Systematics is an alliance of researchers from several institutions in south-west Colombia dedicated to the research and sustainable management of the flora and associated ecosystems in this biodiverse region. Research activities of the group are carried out in both the biodiversity hotspots of the regions: The Chocó biogeographic region on the Colombian Pacific coast; and the Tropical Andes region. The research group was registered in the Colombian System for Science and Technology in COLCIENCIAS in 2006 and has the endorsement of the Universidad Nacional de Colombia, the Pontificia Universidad Javeriana-Cali, and the Universidad del Pacífico de Buenaventura, Colombia. That of other institutions is in process. The research lines and coordinators are as follows; however. many research projects are collaborative activities among the different members of the group: 1. Plant Ecology (Tupac Otero); 2. Conservation Genetics \& Molecular Ecology (Nicola Flanagan); 3. Diversity, Ecology and Sustainable Use of Vanilla (Robertulio Gonzalez); 4. Plant-Microorganism Interactions (Ana T. MosqueraEspinosa); 5. Plant Systematics and DNA Barcoding (Philip A. Silverstone-Sopkin); 6. Pollination Biology (Marcela Cuartas-Domínguez); 7. Plant Biogeography (Guillermo Reina); 8. Orchid Conservation (Nhora Helena Ospina-Calderón). Each research line has a portfolio of projects, both completed and ongoing. Funding has been obtained at the regional, national, and international levels. Further collaborators are always welcome in order to advance knowledge of this biodiverse region and to develop successful strategies for the conservation and sustainable use of this biodiversity.

\section{Orchids of the cloud forests of Dapa (Valle del Cauca, Colombia): research and conservation of forest treasures}

\author{
Terry Lynn Gartelman-Gonzalez ${ }^{1 *}$, Oscar Alejandro Pérez-Escobar ${ }^{2}$ \\ $\&$ EDICSON PARRA-SÁNCHEZ
}

'DAPAVIVA Environmental Foundation, Yumbo, Valle del Cauca, Colombia; ${ }^{2}$ Faculty of Biology, Ludwig Maximilians Universität, München, Germany; ${ }^{3}$ Faculty of Biology, Universidad Nacional de Colombia, Bogotá, Colombia; *Author for correspondence: azucenadelvalle7@yahoo.com

In the framework of the project "Community building for the conservation of wild orchids and annotated list of Orchidaceae in the cloud forests of Dapa," funded by San Diego County Orchid Society (EE.UU), several orchid inventories were conducted in remnant cloud forests from Dapa 
vicinity (Valle del Cauca, Colombia). Field and herbarium work were carried out, and material from each species found was collected and documented with pictures and field notes; several specimens from VALLE and CUVC herbaria were also studied. As a main result, 121 species of 53 genera were reported, 10 of which are new species and 2 unrecorded species for the Colombian flora. New species and records are represented as following for these genera: Campylocentrum Benth. (1 new species) Epidendrum L. (5 new species), Lepanthes Sw. (3 new species and a new record), Stelis Sw. (1 new species), and Telipogon Kunth (1 new record). Many educational workshops were conducted with several community members in order to communicate to them the importance of orchid diversity and conservation of cloud forest. Cloud forests of Dapa vicinity are highly diverse and host an important number of Colombian endemic orchid species, although they were disturbed in the last 30 years by the surrounding community that selectively extracted timber trees and orchids. Primary conservation strategies concerning protection of wild orchid populations and their habitats should be formulated and executed in concert with local community and environmental authorities in order to stop the habitat loss of wild orchid populations.

\title{
Distribution pattern, conservation status, and traditional therapeutic uses of orchids with particular reference to Solan district, Himachal Pradesh, India
}

\author{
K. C. Mahant ${ }^{1 *}$, Promila Pathak ${ }^{2} \&$ Kumar Sharma Vinay $^{1}$ \\ ${ }^{1}$ Department of Botany, Govt. P. G. College, Nalagarh - 174 101, Himachal Pradesh, India; ${ }^{2}$ Orchid Laboratory, \\ Botany Department, Panjab University, Chadigarh - 160 014, India \\ *Author for correspondence: kcmahant@yahoo.co.in
}

The state of Himachal Pradesh in India situated between $30^{\circ} 22^{\prime} 40^{\prime \prime}$ to $33^{\circ} 12^{\prime} 40^{\prime \prime}$ North latitude and $75^{\circ} 45^{\prime} 55^{\prime \prime}$ to $79^{\circ} 04^{\prime} 20^{\prime \prime}$ East longitude, with an altitudinal range of $350 \mathrm{~m}$ to $6,975 \mathrm{~m}$, forms the part of Trans and North Western Himalayan biogeographic provinces. Presently, extensive field surveys were made in the Solan district in the state of Himachal Pradesh during which frequent visits were made in and around the orchid-rich grasslands and forest belts. During the survey, local people and community were also interviewed to gather information on traditional therapeutic uses of these orchids, and a simple questionnaire was prepared for this purpose. The present communication provides brief notes on the distribution pattern, flowering period, conservation status, and traditional therapeutic uses of some of the orchids from the district. However, the great orchid diversity of Himachal Pradesh is progressively declining for a number of reasons, including habitat destruction and illegal and unregulated commercial collections for ornamental and/or medicinal purposes. These factors have detrimentally affected the size and frequency of natural populations of these orchid species, and the existence of many others is threatened. If the depletion of orchids continues unchecked, a large number of species may vanish even before their existence and biological/economic importance is established. Hence, there is an urgent need to identify and document orchids from the region and find appropriate conservation strategies to protect these from becoming extinct. 